\title{
Practices and Beliefs of Private Practitioners Surrounding Discounted Veterinary Services and Products
}

\author{
Lori R. Kogan ${ }^{*}$, , Sherry M. Stewart ${ }^{1}$, Kristy L. Dowers ${ }^{1}$, Regina Schoenfeld-Tacher ${ }^{2}$ and \\ Peter W. Hellyer \\ ${ }^{1}$ College of Veterinary Medicine and Biomedical Sciences, Colorado State University, Fort Collins, CO 80523-1601, \\ USA \\ ${ }^{2}$ College of Veterinary Medicine, North Carolina State University, 1060 William Moore Dr, CVM Main Building, Box \\ 8401, Raleigh, NC 27607, USA
}

\begin{abstract}
Impacted by educational debt and stagnant salaries, the financial viability of a career in veterinary medicine is a growing concern for many within the veterinary profession. Many veterinarians are small business owners, which requires them to learn and practice good business and practice management skills. Despite the recognized importance of business skills to the success of the veterinary profession, training in this area has been historically limited. An important part of practice management skills involves policies and practices surrounding pro-bono and discounted services and products.

To assess private practice veterinarians' practices and beliefs surrounding discounted products and services, an anonymous online survey was distributed through Veterinary Information Network (VIN). Results from the survey suggest that most veterinarians regularly discount veterinary services and products. The reasons reported as most important in determining service discounts were a concern for providing the best possible care for the animal and doing everything possible for the animal. Results were similar for discounting products, but also included the additional reason of encouraging clients to try a product. Regardless of the reasons given for discounting, most veterinarians reported not tracking their discounting practices. These results suggest that despite the fact that most US veterinary schools have been offering practice management courses for many years, there appears to be low adoption levels of at least some widely accepted best-practice business models. It is recommended that providing additional training to help guide philanthropic veterinarians is critical to supporting their financial security and thereby the future of the small animal practitioner.
\end{abstract}

Keywords: Discount, discount veterinary services, private practice, pro-bono, veterinary business management, veterinary economics.

\section{INTRODUCTION}

The questionable viability of a private veterinary practice is a primary topic of discussion among veterinary professionals in both academia and the field. Part of this equation is the rising cost of veterinary school, which is significantly intensified by the rate of inflation and the resultant educational debt [1]. The median tuition for one year of out-of-state tuition at a United States [US] veterinary school, including fees and living expenses, is $\$ 63,000$, and for the $90 \%$ of 2011 graduates with debt, the mean student debt was $\$ 142,613[2,3]$. At the same time, starting salaries of veterinarians have declined by approximately $13 \%$ in the last decade [2]. The mean first year full-time salary for 2013 US veterinary graduates entering private practice was $\$ 67,535$ [4]. The total amount earned by each year's graduating class has been declining since 2008, largely due to the fact that fewer graduates are able to obtain a job, and

*Address correspondence to this author at the College of Veterinary Medicine and Biomedical Sciences, Colorado State University, 1601 Campus Delivery, Fort Collins, CO 80523-1601, USA;

Tel: 970 491-7984; E-mail: Lori.Kogan@colostate.edu can be explained by oversupply. It has been estimated that in 2012 , the US supply of veterinarians was 90,200, exceeding the demand for veterinary services by about 11,250 full-time equivalent veterinarians [6]. This excess capacity is projected to range from $11 \%-14 \%$ through 2025 [7].

At the same time, most US veterinary schools are increasing class size and several new veterinary schools are slated to open in the next few years, adding to the oversupply concern voiced among practicing veterinarians [8]. Although there is an effort to diversify career options of graduating veterinary students, most graduates still hope to work in small or mixed animal private practice. When surveyed, $60.7 \%$ of the new 2013 US graduates were seeking a private practice position. Another $34.8 \%$ of new graduates were seeking advanced education, usually as additional training prior to a career in private practice. In addition to oversupply, veterinarians are increasingly faced with competition for pet health care from other venues (e.g., retail stores, online services, etc.); all of which siphon business from traditional animal hospitals [9].

For many veterinarians working in private practice, part of the plan is to own one's own business, creating the 
necessity to not only be knowledgeable about veterinary medicine, but also business and practice management skills. A veterinary practice is a service business and comes with all the demands that one expects from such an enterprise [10]. Despite the recognized importance of business skills to the success of the veterinary profession, training in this area has historically been quite limited [11-15]. This deficiency in business acumen has been noted among several studies including a 2009 national survey in which veterinary students were asked to respond to an online basic business concepts 'quiz'[12]. The authors found the overall average quiz 'grade' to be a C-minus [16].

In response, many veterinary schools have begun offering some type of business management training. Additionally the Veterinary Business Management Association [VBMA], founded in 2001, has established chapters in each US veterinary school. VBMA, led and managed by veterinary students, offers resources and tools from organizations such as American Animal Hospital Association [AAHA] and American Veterinary Medical Association [AVMA] to help educate students on business related issues [17]. In addition to opportunities within veterinary educational programs, several veterinary organizations offer tools for business owners and students (e.g., AAHA, AVMA, and Veterinary Information Network Inc [VIN], etc.) [18-20]. Veterinarians can also access continuing education [CE] courses related to business through many avenues and colleges. There are many critical areas within practice management that are part of a necessary general business education, but the one focused on in the current study is that of providing pro-bono work and discounts.

\section{Public Perception of Veterinarians and Discounted and Pro Bono Work}

Veterinarians have long enjoyed a reputation as compassionate, caring, and ethical individuals. Notwithstanding some recent negative press (e.g., a televised $20 / 20$ show suggesting that some veterinarians promote unnecessary tests and procedures) [21], the veterinary profession consistently rates extremely high in perceived honesty and ethics [22]. It is likely that at least part of this perception comes from the philanthropic nature of many veterinarians who have a desire to give to the people and animals in their community. Although there are many reasons that businesses and professionals within these organizations may choose to discount specific services two overarching categories include the use of discounts as strategic marketing and business tools, and charity or probono work. It is suggested that, similar to lawyers and medical doctors, the practice of discounting veterinary services or providing pro-bono work is expected by at least a segment of the general population and perhaps the veterinary field itself $[22,23]$.

In addition to philanthropic reasons for discounting, many companies use discounts as a strategy to build their business or create client loyalty. One type of discounting that has exploded in several service-related industries is the use of social media coupons like Groupon. Research on the effectiveness of Groupon type coupons has suggested that these voucher discounts influence company ratings differently based on type of business being discounted and are not always a positive marketing strategy [24].

Either through voucher type discounts or more traditional discounting practices, common examples of discounted veterinary services include free or discounted exams to gain new clients or discounted procedures such as dental cleanings in an effort to help motivate clients to start regular preventative care. Products can also be discounted with the intention of encouraging clients to try something new at a minimal risk. This can be especially important since unlike medical doctors, veterinarians are involved with the sale of prescription medications, food, dietary supplements and merchandise. In this way, veterinarians are similar to ophthalmologists, who prescribe and sell glasses. Yet the median ophthalmologist's average salary is significantly higher than that of a veterinarian; $\$ 257,000$ per year compared to $\$ 82,000$ [25].

These financially challenging times necessitate the need to investigate private practitioners' business and marketing strategies and, in particular, how veterinarians are currently employing discounts for both services and products. This study was therefore designed to assess the current practices and beliefs of veterinarians as they relate to discounted services and products.

\section{MATERIALS AND METHODOLOGY}

An anonymous survey was distributed through VIN from November 2013-January 2014 to all VIN members. Those members who indicated they were working in private practice were asked to complete the online survey which consisted of basic demographic questions, followed by questions on current practices regarding discounting services and products and participants' views on these practices.

\section{RESULTS}

The total number of respondents was 989, of which 963 indicated working in private practice. The majority (936, $97.7 \%$ ) reported working with small animals (dogs and cats). Over one-half of respondents had been in practice more than 15 years $(539 ; 56.2 \%)$, with others reporting $11-15$ years $(119,12.4 \%), 6-10$ years $(111,11.6 \%), 2-5$ years $(119$, $12.4 \%$ ), and less than 2 years $(71,7.4 \%$ ) (4 did not respond).

When asked about their current position, the majority $(479,51.2 \%)$ indicated being sole owners, followed by $(304$, $32.5 \%)$ associate or staff veterinarians, partners (141, $15.1 \%)$, relief veterinarians $(10,1.1 \%)$, and other $(2,0.2 \%)$ and 27 did not answer. Female respondents numbered 592 $(61.8 \%)$ and males numbered $366(38.2 \%)$ with 5 not responding. The most common practice setting was suburban, reported by 451 participants $(47.1 \%)$ followed by urban $(217,22.7 \%)$, small town $(175,18.3 \%)$, and rural $(115,12.0 \%)$ and 5 no response. Ages ranged from 20-29 years old $(85,8.9 \%), 30-39(206,21.5 \%), 40-49$ (245, $25.5 \%), 50-59(292,30.4 \%), 60-69(117,12.2 \%)$, and 70 or older $(14,1.5 \%)$ and 4 did not respond.

Practitioners were asked to report if their clinic discounted services and/or products. The majority $(568,59.0 \%)$ reported discounting both services and products while $302(31.4 \%)$ discounted only services, $18(1.9 \%)$ only products and 75 $(7.8 \%)$ reported that they didn't discount either. 


\section{Discounting Services}

To assess personal ability to discount, participants were asked if they have the authority to discount either services or products. When queried about services, 870 participants responded, of which $653(75.1 \%)$ reported having full authority to discount, $133(15.3 \%)$ had limited authority or required permission from a senior staff member, $61(7.0 \%)$ did not have the ability to discount, but their clinic had discounting policies and $23(2.6 \%)$ had no ability to discount services.

When those who could discount were asked how frequently they discounted services $(n=847$, the largest number reported several times a month $(272,32.2 \%)$ or several times a year $(264,31.3 \%)$, yet a substantial number discounted several times a week $(180,21.3 \%)$ or at least daily $(122,14.5 \%)$. Only $6(0.7 \%)$ reported never. The mean percent of discount was $14.2 \%(\mathrm{SD} 11.0)$, median $=10$, mode $=10(\mathrm{n}=817)$.

Participants who reported either having full authority or limited authority to determine discounts $(n=786)$, were asked to assess the importance of several factors as they relate to the decision to discount services. These factors included: concern about providing the best care possible for the animal, feeling uncomfortable talking about money, feeling good about doing everything possible for the animal, public obligation, and client pressure. The reasons reported as most important included concern for providing the best possible care for the animal (extremely or very important: 526, $66.9 \%$ ), and doing everything possible for the animal (extremely or very important: 348, 44.3\%). Discomfort talking to clients about money, public obligation, and pressure from clients were not felt to be as important in determining discounts for veterinary products (Table $\mathbf{1}$ ).

Regardless of reason for discounting services, most veterinarians reported not tracking their discounted services: $590(75.1 \%)$ said they do not track discounted services and only $185(23.2 \%)$ said they do track discounted services (11 did not respond).

\section{Discounting Products}

When queried about discounting products, $(n=508)$, the majority $358(70.5 \%)$ of veterinarians reported having full authority to discount, $62(12.2 \%)$ had limited authority or required permission from a senior staff member, $59(11.6 \%)$ did not have the ability to discount, but their clinic had discounting policies, and $29(5.7 \%)$ had no ability to discount services.

When those who could discount were asked how frequently they discounted products $(n=479$, the largest number reported several times a year $(182,38.2 \%)$ or several times a month $(14,29.6 \%)$, yet $82(17.2 \%)$ discounted several times a week, and $53(11.1 \%)$ at least daily. Only 19 $(4.0 \%)$ reported never discounting products. The average percent of discount $(\mathrm{n}=435)$ was $15.13 \%$ (SD 12.27), median $=10 \%$, mode $=10 \%$.

Several factors related to discounting products were assessed for importance level similar to the factors for discounting services but with the addition of encouraging clients to try the product. Only participants who reported either having full or limited authority to determine product discounts were included in these analysis $(n=420)$. The reasons felt to be most important were: concern for the best possible care of the animal (extremely or very important: $205,48.8 \%$ ), to encourage clients to try a product (extremely or very important: $150,35.8 \%$ ), and doing everything possible to make the animal feel better (extremely or very important: 142, 33.8\%) (Table 2).

When asked if they track discounted products $(n=420)$, $315(75 \%)$ said they do not track discounted products, 78 $(18.6 \%)$ said yes, and 27 (6.4\%) did not answer. To further assess feelings related to finances, participants were asked to rate their comfort level talking with clients about costs $(n=$ 984). Fifteen percent $(n=151)$ reported feeling comfortable and enjoyed talking about costs, $50 \%$ of respondents $(n=492)$ responded they feel comfortable with this topic but do not enjoy talking to clients about costs, and $15.6 \%$ (154) reported feeling uncomfortable talking about costs with clients.

\section{Discount Frequency and Amount by Gender Age and Years in Practice}

Chi Square was used to examine any differences based on gender, age, setting, and amount of time in practice on frequency, average amount, and reasons to discount. Due to the number of analyses, a more conservative significance

Table 1. Reasons to discount services $(n=786)$.

\begin{tabular}{|c|c|c|c|c|c|c|}
\hline Services & $\begin{array}{l}\text { Extremely } \\
\text { Important }\end{array}$ & $\begin{array}{c}\text { Very } \\
\text { Important }\end{array}$ & $\begin{array}{l}\text { Somewhat } \\
\text { Important }\end{array}$ & $\begin{array}{l}\text { Minimally } \\
\text { Important }\end{array}$ & $\begin{array}{c}\text { Not Important } \\
\text { at All }\end{array}$ & $\mathbf{N A}$ \\
\hline Provide best care possible for animal & $\begin{array}{c}301 \\
38.3 \%\end{array}$ & $\begin{array}{c}225 \\
28.6 \%\end{array}$ & $\begin{array}{c}107 \\
13.6 \%\end{array}$ & $\begin{array}{c}69 \\
8.8 \%\end{array}$ & $\begin{array}{c}66 \\
8.4 \%\end{array}$ & $\begin{array}{c}18 \\
2.3 \%\end{array}$ \\
\hline Do everything possible for the animal makes me feel good & $\begin{array}{c}121 \\
15.4 \%\end{array}$ & $\begin{array}{c}227 \\
28.9 \%\end{array}$ & $\begin{array}{c}206 \\
26.2 \%\end{array}$ & $\begin{array}{c}90 \\
11.5 \%\end{array}$ & $\begin{array}{c}118 \\
15.0 \%\end{array}$ & $\begin{array}{c}24 \\
3.1 \%\end{array}$ \\
\hline Part of my obligation to the public & $\begin{array}{c}45 \\
5.7 \%\end{array}$ & $\begin{array}{c}107 \\
13.6 \%\end{array}$ & $\begin{array}{c}174 \\
22.1 \%\end{array}$ & $\begin{array}{c}188 \\
23.9 \%\end{array}$ & $\begin{array}{c}245 \\
31.2 \%\end{array}$ & $\begin{array}{c}27 \\
3.4 \%\end{array}$ \\
\hline Uncomfortable talking about money & $\begin{array}{c}22 \\
2.8 \%\end{array}$ & $\begin{array}{c}79 \\
10.1 \%\end{array}$ & $\begin{array}{c}137 \\
17.4 \%\end{array}$ & $\begin{array}{c}236 \\
30.0 \%\end{array}$ & $\begin{array}{c}288 \\
36.6 \%\end{array}$ & $\begin{array}{c}24 \\
3.1 \%\end{array}$ \\
\hline Feel pressure from clients to discount services & $\begin{array}{c}28 \\
3.6 \%\end{array}$ & $\begin{array}{c}69 \\
8.8 \%\end{array}$ & $\begin{array}{c}140 \\
17.8 \%\end{array}$ & $\begin{array}{c}239 \\
30.4 \%\end{array}$ & $\begin{array}{c}288 \\
36.6 \%\end{array}$ & $\begin{array}{c}22 \\
2.8 \%\end{array}$ \\
\hline
\end{tabular}


Table 2. Reasons to discount products $(n=420)$.

\begin{tabular}{|c|c|c|c|c|c|c|}
\hline Products $n=420$ & $\begin{array}{l}\text { Extremely } \\
\text { Important }\end{array}$ & $\begin{array}{c}\text { Very } \\
\text { Important }\end{array}$ & $\begin{array}{l}\text { Somewhat } \\
\text { Important }\end{array}$ & $\begin{array}{l}\text { Minimally } \\
\text { Important }\end{array}$ & $\begin{array}{c}\text { Not Important } \\
\text { at All }\end{array}$ & NA \\
\hline Provide best care possible for animal & $\begin{array}{c}101 \\
24.0 \%\end{array}$ & $\begin{array}{c}104 \\
24.8 \%\end{array}$ & $\begin{array}{c}81 \\
19.3 \%\end{array}$ & $\begin{array}{c}46 \\
11.0 \%\end{array}$ & $\begin{array}{c}52 \\
12.4 \%\end{array}$ & $\begin{array}{c}36 \\
(8.6 \%)\end{array}$ \\
\hline Encourage client to try the product & $\begin{array}{c}46 \\
11.0 \%\end{array}$ & $\begin{array}{c}104 \\
24.8 \%\end{array}$ & $\begin{array}{c}85 \\
20.2 \%\end{array}$ & $\begin{array}{c}58 \\
13.8 \%\end{array}$ & $\begin{array}{c}89 \\
21.2 \%\end{array}$ & $38(9.0 \%)$ \\
\hline Do everything possible for the animal makes me feel good & $\begin{array}{c}41 \\
9.8 \%\end{array}$ & $\begin{array}{c}101 \\
24.0 \%\end{array}$ & $\begin{array}{c}96 \\
22.9 \%\end{array}$ & $\begin{array}{c}68 \\
16.2 \%\end{array}$ & $\begin{array}{c}81 \\
19.3 \%\end{array}$ & $\begin{array}{c}33 \\
(7.9 \%)\end{array}$ \\
\hline Uncomfortable talking about money & $\begin{array}{c}14 \\
3.3 \%\end{array}$ & $\begin{array}{c}36 \\
8.6 \%\end{array}$ & $\begin{array}{c}58 \\
13.8 \%\end{array}$ & $\begin{array}{c}104 \\
24.8 \%\end{array}$ & $\begin{array}{c}174 \\
41.4 \%\end{array}$ & $\begin{array}{c}34 \\
(8.1 \%)\end{array}$ \\
\hline Part of my obligation to the public & $\begin{array}{c}7 \\
1.7 \%\end{array}$ & $\begin{array}{c}35 \\
8.3 \%\end{array}$ & $\begin{array}{c}86 \\
20.5 \%\end{array}$ & $\begin{array}{c}103 \\
24.5 \%\end{array}$ & $\begin{array}{c}151 \\
36.0 \%\end{array}$ & $\begin{array}{c}38 \\
(9.0 \%)\end{array}$ \\
\hline Feel pressure from clients to discount products & $\begin{array}{c}22 \\
5.2 \%\end{array}$ & $\begin{array}{c}53 \\
12.6 \%\end{array}$ & $\begin{array}{c}47 \\
11.2 \%\end{array}$ & $\begin{array}{c}95 \\
22.6 \%\end{array}$ & $\begin{array}{c}170 \\
40.5 \%\end{array}$ & $\begin{array}{c}33 \\
(7.9 \%)\end{array}$ \\
\hline
\end{tabular}

level of $\mathrm{p}<.01$ was used to determine statistical significance. Only respondents who reported they had full authority to discount were included in the analysis $(n=653)$. When these responses were analyzed, there were no significant differences in frequency or amount of discounted services based on age, gender, or years in practice. While the practice setting (rural, suburban, or urban) did not impact frequency of discounting, there was a significant difference in amount of discount with practices in rural settings $(n=78)$, reporting the highest mean (15.32, SD 12.75), followed by suburban practices $(n=299$; mean $=14.28$, SD 9.6); urban practices $(\mathrm{n}=138$; Mean $=13.41, \mathrm{SD} 10.5)$ and small town practices $(\mathrm{n}=121 ; 13.23$, SD 10.96) $(\mathrm{F}=3.885, \mathrm{p}=0.004)$. The prevalence of tracking discounted services was not different based on gender, age, or years in practice.

Chi Square was also used to detect differences based on gender, age, and amount of time in practice on frequency, average amount, and reasons to discount for those who reported full authority to discount products $(n=358)$. Age, gender, and practice setting did not influence frequency or amount of discounted products. The frequency of discounting products was significantly different based on number of years in practice, with those in practice longer discounting more often $(n=358)$ (Table 3) (Chi Square, 48.34 , df $25, p=0.003$ ), but the amount of discount was not significantly different. The prevalence of tracking discounted products was not different based on gender, age, or years in practice.

\section{Reasons to Discount}

Participants were asked to identify the situations and types of individuals and animals for whom they provided discounted services. This analysis included only those who reported being fully or partly able to discount services $(\mathrm{n}=786)$.

The specific populations most commonly offered discounts included staff members $(87.8 \%)$, professional colleagues $(63.7 \%)$ and family members $(60.9 \%)$. Rescue organizations were the most commonly discounted organization type $(60.2 \%)$. Other top discount categories included: complications from surgery or other procedure performed $(64.9 \%)$, rechecks on same problem $(55.6 \%)$; multiple animal discounts for litters (52.7\%); multiple animal discounts for physical exams (48.6\%); and the

Table 3. Frequency of discounted products by years in practice.

\begin{tabular}{|c|c|c|c|c|c|}
\hline Years in Practice & At Least Daily & Several Times a Week & Several Times a Month & Several Times a Year & Never \\
\hline Less than 2 & 1 & 1 & 1 & 4 & 2 \\
\hline \multirow[t]{2}{*}{$2-5$} & -- & 2 & 3 & 7 & 3 \\
\hline & -- & $13.3 \%$ & $20 \%$ & $36.7 \%$ & $20 \%$ \\
\hline $6-10$ & -- & $22.9 \%$ & $37.1 \%$ & $40.0 \%$ & -- \\
\hline \multirow[t]{2}{*}{$11-15$} & 6 & 8 & 12 & 18 & 2 \\
\hline & $13 \%$ & $17.4 \%$ & $26.1 \%$ & $39.1 \%$ & $4.3 \%$ \\
\hline More than 15 & 30 & 47 & 76 & 96 & 2 \\
\hline
\end{tabular}


Table 4. Endorsement rate for reasons to discount.

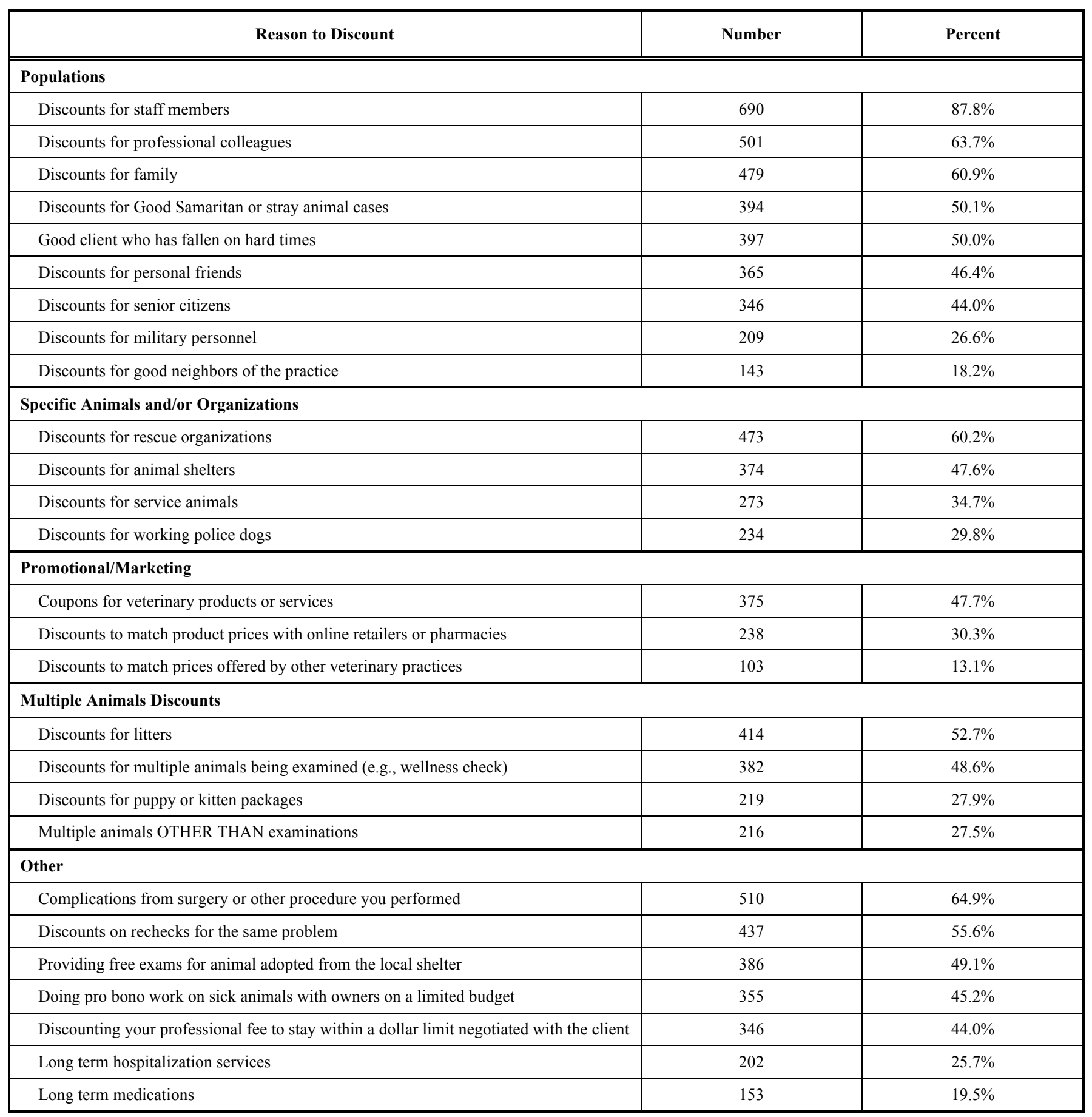

provision of free exams for animals adopted from the local shelter (49.1\%). Overall, the top reason for discounting was providing discounts for staff members; a practice done by the majority of participants (Table 4).

The remaining questions on the survey pertained to perceptions of cost and discounting in general. Therefore, all participants working in private practice were included in the analysis $(n=984)$.

\section{Cost of Veterinary Services and Products}

When veterinarians were asked about their perception of the cost of veterinary products and services, most respondents reported feeling that neither veterinary products $(699 ; 71 \%)$ nor veterinary services $(705 ; 71.6 \%)$ were too expensive for most people. Participants were also asked if they felt that clients expect discounted or free services or products. Less than one-half $(432,43.9 \%)$ reported feeling clients expect discounted services and 316 (32.1\%) reported feeling clients expect free services. When asked about products, $339(34.4 \%)$ felt clients expect discounted products and $163(16.6 \%)$ felt clients expect free products (Table 5).

In addition to asking respondents to report on the actual discounts they provide, participants were asked more generally to indicate their support for reasons a veterinarian 
Table 5. Veterinarians' perceptions of clients' expectations of free and discounted services and products.

\begin{tabular}{|c|c|c|c|c|c|}
\hline & Do Not Agree at All & Do Not Really Agree & Somewhat Agree & Strongly Agree & NA \\
\hline \hline Clients expect discounted services & $166(16.9 \%)$ & $335(34.0 \%)$ & $306(31.1 \%)$ & $126(12.8 \%)$ & $51(5.2 \%)$ \\
\hline Clients expect free services & $333(33.8 \%)$ & $286(29.1 \%)$ & $214(21.7 \%)$ & $102(10.4 \%)$ & $49(33.8 \%)$ \\
\hline Clients expect discounted products & $252(25.6 \%)$ & $342(34.8 \%)$ & $250(25.4 \%)$ & $89(9.0 \%)$ & $512(5.2 \%)$ \\
\hline Clients expect free products & $435(44.2 \%)$ & $336(34.1 \%)$ & $107(10.9 \%)$ & $56(5.7 \%)$ & $50(5.1 \%)$ \\
\hline
\end{tabular}

might choose to discount. This question therefore included all participants, regardless of their personal ability to discount services or products. The types and reasons for discounts that were supported by most participating veterinarians included discounts for professional colleagues and Care Credit. Areas with the least support included coupons and discounts for multiple animals being vaccinated or examined at the same appointment (Table 6).

\section{DISCUSSION}

Results from this study support the premise that most veterinarians are generous and want to do everything possible to care for animals. The majority of veterinarians who completed the survey indicated having the authority to discount services and products, and nearly all of these veterinarians reported discounting services, with over onethird of them discounting their services at least several times a week, by an average of $14.2 \%$. The top reasons these veterinarians gave for discounting services were a concern for the best possible care of the animal and doing everything possible for the animal.
The frequency of discounting products was only slightly lower than that of services, with $28.3 \%$ of veterinarians reporting discounting products at least several times a week, at an average discount of $15.1 \%$. The reasons for discounting products were the same as those for services. Concern for animal care and doing everything possible to make an animal feel better still were the most common reasons stated but reasons for discounting products also included the desire to encourage clients to try a product.

Regardless of the reasons given for discounting, however, most veterinarians reported not tracking their discounts. Only $18.6 \%$ reported tracking discounted products and $23.2 \%$ tracking discounted services. Approximately $75 \%$ of respondents indicated not tracking discounted services or products.

To determine if part of the reason behind discounting might be perceived client pressure, veterinarians were asked how important they felt client pressure to discount was in their decision. For both services and products, this reason was near the bottom of the list. Furthermore, when asked to indicate their comfort level talking to clients about money,

Table 6. Reported support for discount types.

\begin{tabular}{|c|c|c|c|c|c|}
\hline & Strongly Support & Support & Somewhat Opposed & Very Opposed & NA \\
\hline Discounts for professional colleagues & $552(56.1 \%)$ & $292(29.7 \%)$ & $58(5.9 \%)$ & $24(2.4 \%)$ & $58(5.9 \%)$ \\
\hline Care credit & $458(46.5 \%)$ & $301(30.6 \%)$ & $75(7.6 \%)$ & $81(8.2 \%)$ & $69(7.0 \%)$ \\
\hline Discounts on rechecks for the same problem & $391(39.7 \%)$ & $331(33.6 \%)$ & $123(12.5 \%)$ & $71(7.2 \%)$ & $68(6.9 \%)$ \\
\hline Discounts for rescue organizations & $379(38.5 \%)$ & $340(34.6 \%)$ & $122(12.4 \%)$ & $77(7.8 \%)$ & $66(6.7 \%)$ \\
\hline Discounts for service animals & $362(36.8 \%)$ & $389(39.5 \%)$ & $124(12.6 \%)$ & $46(4.7 \%)$ & $63(6.4 \%)$ \\
\hline Providing free exams for animal adopted from the local shelter & $325(33.0 \%)$ & $311(31.6 \%)$ & $170(17.3 \%)$ & $112(11.4 \%)$ & $66(6.7 \%)$ \\
\hline Discounts for good Samaritan or stray animal cases & $321(32.6 \%)$ & $417(42.4 \%)$ & $133(13.5 \%)$ & $52(5.3 \%)$ & $61(6.2 \%)$ \\
\hline Discounts for senior citizens & $286(29.1 \%)$ & $349(35.5 \%)$ & $190(19.3 \%)$ & $91(9.2 \%)$ & $68(6.9 \%)$ \\
\hline Discounts for military personnel & $276(28.0 \%)$ & $397(40.3 \%)$ & $166(16.9 \%)$ & $72(7.3 \%)$ & $73(7.4 \%)$ \\
\hline $\begin{array}{l}\text { Discounts for multiple animals being examined } \\
\text { (e.g., wellness check) }\end{array}$ & $218(22.2 \%)$ & $291(29.6 \%)$ & $200(20.3 \%)$ & $213(21.6 \%)$ & $62(6.3 \%)$ \\
\hline Discounts for multiple animals being vaccinated & $184(18.7 \%)$ & $298(30.3 \%)$ & $214(21.7 \%)$ & $227(23.1 \%)$ & $61(6.2 \%)$ \\
\hline $\begin{array}{l}\text { Discounting your professional fee to stay } \\
\text { within a dollar limit negotiated with the client }\end{array}$ & $166(16.9 \%)$ & $354(36.0 \%)$ & $229(23.3 \%)$ & $171(17.4 \%)$ & $64(6.5 \%)$ \\
\hline $\begin{array}{c}\text { Doing pro bono work on sick animals with } \\
\text { owners on a limited budget }\end{array}$ & $139(14.1 \%)$ & $409(41.6 \%)$ & $270(27.4 \%)$ & $101(10.3 \%)$ & $65(6.6 \%)$ \\
\hline Discounts for good neighbors of the practice & $122(12.4 \%)$ & $395(40.1 \%)$ & $263(26.7 \%)$ & $127(12.9 \%)$ & $77(7.8 \%)$ \\
\hline Providing coupons for veterinary products or services & $111(11.3 \%)$ & $358(36.4 \%)$ & $222(22.6 \%)$ & $228(23.2 \%)$ & $65(6.6 \%)$ \\
\hline
\end{tabular}


most participants reported feeling comfortable, if not necessarily enjoying the topic.

The fact that veterinarians did not report perceived pressure from clients as an important factor in discounting was especially interesting given that many veterinarians reported feeling that clients expect free or discounted services and products. In fact, $43.9 \%$ felt that clients expect discounted services and $32.1 \%$ felt clients expect free services. These figures were only slightly lower for products, whereby $34.4 \%$ reported feeling clients expect discounted products and $16.2 \%$ that clients expect free products. In addition, most veterinarians reported feeling that neither veterinary services nor products are too expensive for most people. These factors suggest that veterinarians are not choosing to discount because of perceived pressure from clients or an overall discomfort talking about money. They are discounting for philanthropic or business management reasons.

When assessing any differences in discounting practices based on demographics, only minimal differences were found. Regardless of age, gender, geographical setting or years in practice, the amount and frequency of discounting was stable. In fact the only significant differences found were that veterinarians in practice longer reported discounting products slightly more frequently than those in practice fewer years, yet the amount of discount was the same. For services, the only difference was found in geographical setting, whereas veterinarians from rural settings reported the highest mean discount percentage followed by suburban; urban and small town. Although these differences were statistically significant, the amount of percentage differences was not substantial $(2.09 \%$ between the largest and smallest percentage).

When participants were asked to report the situations and types of individuals and animals for whom they provided discounted services, the top reason for discounting was to provide discounts for staff members; a practice acknowledged by the majority of participants. This is similar to traditions in other areas, such as retail, where employees also receive discounts for shopping at a particular company. Other prominent groups benefitting from discounts include professional colleagues, family members, rescue organizations, and clients with complications from surgery or other procedures performed. Upon reviewing the responses to the 'other' category, two additional areas were mentioned by several respondents. These included discounting for clients with whom something besides surgery had gone wrong (e.g., waited too long, bad service, etc.) and veterinarians who wanted to try a new medical procedure, protocol or continue treatment to assess the impact on the patient's health.

Clearly, there are many reasons that veterinarians choose to provide discounts. While some reasons are clearly designed to increase business or be more competitive (i.e., coupons for discounted products or services, discounts to match product prices with online retailers or pharmacies, or to match prices offered by other veterinary practices), the driving force behind most discounts appears to be more philanthropic in nature.
Similar to other occupations, such as lawyers and other health care professionals, there appears to be an expectation from both the public and professionals themselves to offer some amount of pro-bono work [23]. The type of pro-bono work most often seen in veterinary medicine is an ad hoc, individual approach as opposed to an organized, systematic approach. This typically entails private practitioners providing pro-bono services on their own accord out of a sense of passion or duty. This is very similar to the type of ad hoc pro-bono work done by many lawyers [23].

Like veterinarians, research suggests that lawyers provide pro-bono services for a variety of reasons, some because of personal values or desires to provide a public service, and others as a means to create or increase business [23]. Not surprisingly, it has also been shown that attorneys offer more pro-bono services when they feel they can afford to do so. A study of participation rates across the country found that states in which lawyers were more financially successful also had higher rates of lawyer participation in organized pro bono programs. It makes sense that higher profits permit lawyers to offer more pro-bono labor, meaning that clients in need benefit from financially successful practices. It seems natural to assume similar trends can be found in veterinary medicine; financially successful professionals have more to give. This ability to act philanthropically is increasingly important as clinics attempt to hire veterinarians from the millennium generation.

Philanthropic by nature [26], it is suggested that millennium generation veterinarians will be more attracted to practices solvent enough to allow employees the opportunity to offer pro-bono or discounted services and this can actually be a successful recruitment tool for new employees. This premise is supported by the fact that law firms believe that they are able to attract and retain better talent because of probono opportunities [23]. It therefore follows that veterinarians who can run a successful practice offer benefits to all those involved.

It is clear that for successful practice owners and partners, competency in veterinary medicine is not enough; they must also be skilled in a number of non-clinical areas, not least of which is business acumen. Yet both graduates and employers have identified the difficulties faced by new graduates in the financial aspects of client communication and valuing their services enough to have the confidence to charge appropriately for them. These findings suggest that veterinary students are still not being adequately equipped with important career business skills [27].

Unfortunately, business skills have long been neglected by the profession and when compared to medical knowledge are still often seen as low priorities by students and faculty $[28,29]$. Despite data to support the expansion of both compulsory and elective veterinary business teaching, it is often difficult to convince students of the relevance of business skills training [27]. Many veterinary students do not place the same value on entrepreneurship and businessrelated education as employers and do not perceive it as a priority within their veterinary studies.

This is in spite of the fact that both the KPMG and Brakke studies recommended several key business and management behaviors and suggested the need for veterinary 
schools to incorporate these business training strategies into their curricula [30]. Many key business practices identified by the 1998 Brakke study have yet to be widely implemented. It does not help that recent graduates have been shown to rate themselves significantly more proficient than employers considered them to be in financial aspects of a practice and communicating with clients about money [30].

This poses a number of challenges for educators in terms of: seeking to integrate entrepreneurship and business-related topics within already crowded programs of study, determining relevant content and delivery methods, and designing appropriate assessment methods [27]. It is clear that a successful veterinary practice requires a unique combination of medical competence and other professional skills including empathy, communication skills, and business and management skills. The disconnect between faculty perspectives and employer or alumni needs regarding business and leadership skills is striking, especially given the fact that business, management, and marketing skills are desired by many employers of veterinarians [31,32].

It has been suggested, that just as veterinary medicine has changed in other areas, the profession must continue to evolve in the area of veterinary business and management education. Fortunately, the number of those who argue that training veterinarians in business skills should not be part of veterinary curricula is diminishing. Most schools now feel the profession can no longer overlook the importance of business skills [33].

To help address this concern, The North American Veterinary Medical Education Consortium recently included professional and personal business and financial knowledge as core graduate competencies.[34] As a result, a number of schools have incorporated business skills training as part of a wider program of professional skills training in their curricula [35-37]. Options for this training include joint degrees in veterinary medicine and business administration [DVM/MBA][38] or Business Certificates offered with support from the VBMA club [37, 39].

The VBMA, with widespread support in both US and United Kingdom veterinary schools has two levels of a National VBMA Business Certificate Program [37,39]. Chapter officers at each school are able to determine which levels are offered, based on the total number of hours completed. A silver certificate includes 16 hours of education and a gold certificate includes 32 hours. The courses cover four broad categories including: business finance; business operations, management, and ownership; business leadership skills; and career and personal development [40]. VBMA recommends the Business Certificate Program as an opportunity for students to become more knowledgeable about the business aspects of veterinary medicine without the added expense of an additional degree [40].

Unfortunately, despite the fact that most US veterinary schools have been offering practice management courses for many years [30] and many have VBMA Business Certificate Programs, there appears to be low adoption levels of widely accepted best-practice business models [41]. The fact that approximately $75 \%$ of respondents in the current study indicated they do not track discounted or free services or products provide evidence of this challenge. Perhaps even more suggestive of the need for further change is the fact that this percentage does not change based on respondents' age or years in practice, implying that the increased business training in veterinary curricula is still not meeting the needs of the profession.

Therefore, even with the challenges of an over-full curriculum, it appears that exploring additional ways to support the future success of veterinary graduates, in addition to debt and loan knowledge, are the topics of practice management and business skills. Veterinarians care about the wellbeing of their patients and this study suggests one area in which they demonstrate this caring is through discounted services and products offered to many segments of the population. Providing training to help guide these philanthropic individuals on best business practices is critical to supporting their financial security and thereby the future of the small animal practitioner. Far from an area to be delegated to the back corner of veterinary curricula, it is suggested that schools take another look at what else they can do to address this critical issue.

\section{CONFLICT OF INTEREST}

The authors confirm that this article content has no conflict of interest.

\section{ACKNOWLEDGEMENTS}

The authors would like to thank the Veterinary Information Network for making this survey available to its members and Dr. Apryl Steele for helping with survey development.

\section{REFERENCES}

[1] Asch DA, Nicholson S, Vujicic M. Are we in a medical education bubble market? N Engl J Med 2013; 369: 1973-5.

[2] Segal D. High Debt and Falling Demand Trap New Vets, in: The New York Times [on line] (2013) http://www.nytimes.com/2013/ 02/24/business/high-debt-and-falling-demand-trap-newveterinarians.html?_r$=0$ [consulted 16 April 2014].

[3] Larkin M. Higher debt, lower salaries a continuing concern for grads. J Am Vet Med Assoc 2012; 240(3): 248-51. [online] https://www.avma.org/News/JAVMANews/Pages/120201a.aspx [consulted 01 May 2014].

[4] Market research statistics - First year employment. J Am Vet Med Assoc 2014 [on line] https://www.avma.org/KB/Resources/Statisti cs/Pages/Market-research-statistics-First-year-employment.aspx [consulted 29 April 2014].

[5] Myers E. Total Income and Total Debt. Just Vet Data 2014 [on line] http://www.justvetdata.com/total_income_and_total_debt?spl ash $=1$ [consulted 13 April 2014].

[6] AVMA Workforce Report Confirms Excess Capacity in U.S Veterinary Profession. Am Vet Med Assoc website 2013 [on line] http://atwork.avma.org/2013/04/23/avma-workforce-report-confirm s-excess-capacity-in-u-s-veterinary-profession/ [consulted 19 May 2014].

[7] Niedziela K. Only 38\% of Vet Clinics Operating at Full Capacity. Vet Pract News 2013 [on line] http://www.veterinarypracticenews. com/vet-breaking-news/2013/04/23/many-vet-clinics-not-operating -at-full-capacity.aspx [consulted 29 May 2014].

[8] Lau E. When dental schools closed: lessons for veterinary profession? Vet Inform Network Inc [on line] (2013) http://news. vin.com/VINNews.aspx?articleId=27460\#Chart [consulted 06 April 2014].

[9] Lau E. Advising aspiring veterinarians: spur or deter? in: Veterinary Information Network Inc. 2013 [on line] http://news.vin.com/VINNews.aspx?articleId=28103 [consulted 30 April 2014]. 
[10] Dusenberry A. What Specific Skills Do You Need to Be a Veterinarian? Houston Chronicle 2014 [on line] http://work.chron. com/specific-skills-need-veterinarian-9910.html [consulted 03 May 2014].

[11] Bachynsky EA, Baillie S, Dale VH, Gazzard J, Kinnison T. A survey of the opinions of recent veterinary graduates and employers regarding early career business skills. Vet Rec 2013; 172(23): 604 .

[12] Cron WL, Goodnight DB, Slocum JV, Volk JO. Executive summary of the Brakke management and behavior study. J Am Vet Med Assoc 2000; 217:332-338.

[13] Cron WL, Cummings RE, Felsted KE, et al. Executive summary of the AVMA-Pfizer business practices study. J Am Vet Med Assoc 2005; $226: 212-8$

[14] Dudley J. Practices must 'learn lessons' to beat slump. Vet Times 2008.

[15] Henry C, Treanor L. Entrepreneurship education and veterinary medicine: enhancing employable skills. Education + Training 2010; 52(8/9): 607-23

[16] Verdon D. The final exam: National survey tests business acumen of veterinary students; more study needed. DVM News Mag 2009 [on line] http://veterinarynews.dvm360.com/dvm/Veterinary+news/ The-final-exam-National-survey-tests-business-acum/ArticleStanda rd/Article/detail/596430 [consulted 09 April 2014].

[17] Smithers B. Veterinary Business Management Association. Vet Bus Manage Assoc 2014 [on line] http://www.vbma.biz/tools [consulted 09 April 2014].

[18] American Animal Hospital Association 2014 [on line] https://www. aahanet.org/ [consulted 09 April 2014].

[19] American Veterinary Medical Association 2014 [on line] https:// www.avma.org/ [consulted 09 April 2014].

[20] Pion P. Veterinary Information Network, Inc. 2004 http://www.vin. com/ [consulted 09 April 2004].

[21] Launier K, Wagshal G. Is Your Veterinarian Being Honest With You? ABC News 2013 [on line] http://abcnews.go.com/2020/vid eo/veterinarian-honest-20987714 [consulted 25 May 2014]

[22] Nurses Top List of Most Honest and Ethical Professions. Saad L. Gallup News Service 2006 [on line] http://www.gallup.com/poll/ 25888/nurses-top-list-most-honest-ethical-professions.aspx [consulted 28 April 2014].

[23] Cummings SL, Sandefur RL. Beyond the Numbers: What We Know-and Should Know-About American Pro Bono Social. Sci Res Network 2013 [on line] http://papers.ssrn.com/sol3/papers. cfm?abstract_id=2239433 [consulted 09 May 2014].

[24] Ahmen N, Dholakia U, Farafat. Does a Daily Deal Promotion Signal a Distressed Business? An Empirical Investigation of Small Business Survival. Cornell University Library 2012 [on line] http://arxiv.org/abs/1211.1694v1 [consulted 22 May 2014].

[25] Health Care Worker Salaries. Health Care Worker Salaries 2014 [on line] http://www.healthcareworkersalary.com/ [consulted 15 April 2014]

[26] The 2013 Millennial Impact Report. Achieve Guidance 2013 [on line]
http://cdn.trustedpartner.com/docs/library/AchieveMCON2013/Res earch\%20Report/Millennial\%20Impact\%20Research.pdf

[consulted 27 May 2014].

[27] Henry C, Treanor L. Exploring entrepreneurship education within veterinary medicine: can it be taught? J Small Bus Enterprise Dev 2012; 19(3): 484-99.

[28] Rhind SM, Baillie S, Kinnison $\mathrm{T}$, et al. The transition into veterinary practice: opinions of recent graduates and final year students. BMC Med Educ 2011;11: 64.

[29] Lane I, Bogue E. Faculty perspectives regarding the importance and place of nontechnical competencies in veterinary medical education at five North American colleges of veterinary medicine. J Am Vet Med Assoc 2011; 237(1):53-64.

[30] Bachynsky EA, Dale VHM, Kinnison T, Gazzard J, Baillie S. A survey of the opinions of recent veterinary graduates and employers regarding early career business skills. Vet Rec 2013; 172(23): 1 .

[31] Lofstedt J. Confidence and competence of recent veterinary graduates - is there a problem? Can Vet J 2003; 44:359-60.

[32] Kieves NR, Roark AW. Sparks TK. Business education in veterinary schools: the potential role of the Veterinary Business Management Association. J Vet Med Educ 2007; 34: 678-82.

[33] Hardy B. The business of being a vet. Vet Rec 2013; 173(3): 74-5.

[34] North American Veterinary Medical Education Consortium. Roadmap for Veterinary Medical Education in the $21^{\text {st }}$ Century: Responsive, Collaborative, Flexiblein: North American Veterinary Medical Education Consortium 2013 [on line] http://aavmc.org/da ta/files/navmec/navmec_roadmapreport_web_booklet.pdf [consulted 02 May 2014].

[35] Draper DD, Uhlenhopp EK. A veterinary business curriculum model. J Vet Med Educ 2002; 29: 73-80.

[36] Lloyd JW, Bristol DG, Draper DD, McManus JP, Neer CA, Bonvicini KA. Models for teaching career development and practice management. J Vet Med Educ 2004; 31:168-74.

[37] Harris DL, Lloyd JW. Changes in teaching of nontechnical skills, knowledge, aptitudes, and attitudes at US colleges and schools of veterinary medicine between 1999 and 2009. J Am Vet Med Assoc 2011; 239: 762-6.

[38] Kogan LR, McConnell SL, Schoenfeld-Tacher R. Response of a veterinary college to career development needs identified in the KPMG LLP study and the executive summary of the Brakke study: a combined MBA/DVM program, business certificate program, and curricular modifications. J Am Vet Med Assoc 2005; 226: 1070-6.

[39] Kieves NR, Roark AW, Sparks TK. Business education in veterinary schools: the potential role of the Veterinary Business Management Association. J Vet Med Educ 2007; 34: 678-82.

[40] National VBMA Business Certificate Program. Veterinary Business Management Association 2013 [on line] http://www.vbma.biz/national-vbma-business-certificate-program [consulted 11 April 2014].

[41] Volk JO, Felsted KE, Cummings RE, Slocum JW, Cron WL, Ryan KG, Moosbrugger MC. Executive summary of the AVMA-Pfizer business practices study. J Am Vet Med Assoc 2005; 226: 212-8. 